\title{
未成年者を被保険者とする生命保険契約 についての一考察
}

菊池直人

\section{ロアブストラクト}

日本では，未成年者を被保険者とする死亡保険契約について，保険法上特 段の規定はなく，道徳危険については，保険者の自主規制や金融庁の監督に よって対応がなされている。すなわち, 保険金額の相当性および適切な引 受・支払基準の構築，その遵守など，運用上の問題に収束したといえる。一 方，諸外国に目を向けると，未成年者を被保険者とする死亡保険契約につい ては，立法上制限を設ける例が多数みられる。多くの場合，意思能力の有無 を判断材料とし，保険契約を禁止したり，保険金額を制限したりしている。 これは, 被保険者の同意とは, 当該保険について了承する意思表示であると ともに，道徳危険を伴う保険についての自己決定であるとして，未成年者と いえども代理による同意を実質的に認めない。

我が国の未成年者の生命保険契約は, 過去の事例からも道徳危険性は少な いとされてもいるが，意思能力の有無に基づく保険契約上の規制が必要であ ると思われる。

\section{ロキーワード}

他人の生命の保険契約, 被保険者同意, 未成年者の生命保険契約

*平成 25 年 6 月 22 日の日本保険学会関西部会報告による。

/ 平成 26 年 6 月 22 日原稿受領。 


\section{1.はじめに}

\section{（1）未成年者を被保険者とする他人の生命の保険契約}

生命保険契約の当事者以外の者を被保険者とする死亡保険については当該 被保険者の同意がなければ，その効力を生じない（保険法38条）。また，傷 害疾病定額保険契約の当事者以外の者を被保険者とする傷害疾病定額保険契 約は，当該被保険者の同意がなければ，その効力を生じない（保険法 67 条 1 項)。これらの規定は，他人の死亡の保険契約に係る危険性の排除を目的と している。

未成年者を被保険者とする生命保険契約は，我が国においては学資保険な どとして広く周知されており，一定のニーズも存在する1)。一方で，未成年 者を被保険者とする他人の生命の保険契約については，その同意のあり方を めぐり議論があった ${ }^{2)}$ 。特に, 意思能力のない未成年者については法定代理 人による同意をもって処理するしかなく，このような同意を認めるとことは， 実質規定の空洞化となるおそれがあるからである。実務上は，意思能力のあ る未成年者については，本人が同意した上で法定代理人がこれに同意し，意 思能力のない未成年者については法定代理人が未成年者を代理して同意する ということで処理されている3)。

1） (社生命保険協会「2013年度版 生命保険の動向」によれば，平成24年度の個 人保険の種類別新契約件数の約 $4 \%$, 種類別保有契約件数の約 $4 \%$ がこども保 険となっている。

2）大森忠夫 ·保険法〔増補版〕271頁（有斐閣，1985)，西嶋梅治・保険法〔第 三版３24頁（悠々社，1998)，山下友信・保険法272頁（有斐閣，2005）参照。

3）(社生命保険協会による「未成年者を被保険者とする生命保険契約の適切な申 込・引受に関するガイドライン」によれば，「未成年者，特に15歳未満である 場合には，被保険者同意の取得が困難なケースがあることも踏まえ，親権者等 の法定代理人の同意を要することに加えて，引受の審査において，より合理的 な付保額の範囲内であるといった適切な基準を設ける等，モラルリスクの排 除・抑制に更に取組む必要がある。本がイドラインは，未成年者，特に15歳未 満の方が被保険者となる生命保険契約の申込・引受がより一層適切に行われる よう，会員各社が留意すべき事項を策定したものであり，会員各社は本がイド 
保険法の制定にあたり，未成年者を被保険者とする死亡保険契約について は，法務省法制審議会保険法部会においても検討がなされたが，保険法では 特段の規定は設けられなかった。ただし，同審議会においては，未成年者を 被保険者とする死亡保険は禁止すべきという意見や，保険金額に上限を設け るべきという意見も見られた ${ }^{4)}$ 。契約法上の規律は見送られたものの，未成 年者保険について何らかの規制が必要であるとの認識はされており，これに 対しては，保険者による自主規制の策定，および金融庁によるその遵守の監 督という方法がとられた（保険業法施行規則第53条の 7 第 2 項，監督指針 II $-3-5-1-2(15))$ 。

\section{(2) 問題の所存と検討の方向}

我が国において，未成年者を被保険者とする死亡保険は，学資保険等とし て，広く受容されているが，諸外国に目を向けると，未成年者を被保険者と する死亡保険契約については，立法上の制限を設ける例が多数みられる。こ れらの国々では，被保険者の行為能力の有無から，契約そのものを無効とし たり，あるいは保険金額に一定の制限を加えたりする場合が多い。本稿では， 行為能力の視座から, 諸外国での立法上の制限理由について考察し, 日本に おいても立法上の規制が必要なのか検討しようとするものである。

まず，2で日本において未成年者を被保険者とする死亡保険が広く受容さ れた背景を沿革的に考察した後，これまでの学説，自主規制と監督強化の内 容を整理する。次に 3 では，未成年者を被保険者とする保険について多くの 国が規制を置くが，その立法理由について考察し，4でまとめとして日本に おいても何らかの立法上の規制が必要なのか検討を加えたい。

ラインの策定趣旨を踏まえた適正な対応の確保に努めるものとする」とある。 4）未成年者を被保険者とする死亡保険については複数回議論されている。法制 審議会保険法部会議事録第 5 回，7 回，10回，15回，18回，22回参照。 


\section{2. 未成年者を被保険者とする生命保険ついての我が国の状況}

\section{（1）沿 革 一受容の背景一}

我が国において民間生命保険制度が誕生したのは明治期であるが，その当 初から被保険者として保険に加入できる年齢は15歳以上となっていた ${ }^{5)}$ 。ま た，小口保険制度である簡易生命保険 ${ }^{6)}$ においても，加入可能な被保険者の 年齢は12歳以上となっていた7)。ただし，これは当時の社会情勢を鑑みると， 本稿で課題とする未成年者を被保険者とする死亡保険契約とは実情が異なる と思われる。これら保険の補償目的は，働き手を失った場合の遺族補償であ ったと思われるからである8

就業前の未成年者を被保険者とする生命保険は，1931年（昭和 6 年）の簡 易生命保険法の改正を起源とする。逓信省簡易保険局によって発売された小 児保険は, 満 3 歳以上12歳未満の未成年者を対象としていた（後に1938年 (昭和13年), 加入可能年齢は満 1 歳まで引き下げられた)。この保険は，幼 年者を被保険者とした，死亡保障を目的とする生命保険であったが，小児保 険の実施にあたっては，すでに当時も道徳危険が議論されていた9 。ただし，

5）生命保険会社協会編 - 明治大正保険資料第 1 巻第 1 編第 5 類98頁（生命保険 会社協会，1942）。我が国初の民間生命保険会社である明治生命有限会社（当 時）では被保険者の年齢を15歳以上60歳未満としていた。ちなみに，死亡保障 のない学資保険もすでに販売されていた。

6）簡易保険の歴史的展開については，田村祐一郎「簡易保険問題の史的展開 (一)」生命保険文化研究所所報第68号 1 頁以下（1985）参照。簡易保険で想定さ れた契約者層は，民間生保会社が未だ進出していなかった低所得者層であった。 いわば社会保険の代用物であったという。

7）簡易生命保険法（大正 5 年法律第42号，1916年)。

8）我が国の労働基準法の前身ともいえる，工場法（明治44年 3 月 29 日法律第 46 号，1911年）第 2 条 1 項においては, 就業可能な年齢を 12 歳以上としていた。 併せて, 当時の12歳未満の幼少年は死亡率も高く, 保険事業としては敬遠され ていたことも要因かと思われる。(『東京朝日新聞』1931年 3 月 27 日参照)。

9）「逓信省で実施を急ぐ小児保険の制度 困難なのは小児殺の弊害防止」(『大阪 朝日新聞』1928年 5 月 13 日)。 
これについては，簡易保険での保険金額は普通保険と比して少額であること から問題とならないとされ ${ }^{10)}$ ，また，いわゆる「もらい児殺し」の危険を防 止するために契約者は三親等までに制限されていた（後に緩和され継母も契 約者適格とされた)。ちなみに，小児保険の実施にあっては民間保険会社か ら民業圧迫との反対の声が挙がっており, 特に徵兵保険に抵触するとして激 しい反対運動が生じている ${ }^{11)}$ 。

この簡易保険の小児保険は広く普及し，その後の日本郵政公社（現かんぽ 生命）による「学資保険」へと姿を変えたが，基本的には死亡保障を中心と した保険である ${ }^{12)}$ 。「学資保険」は，こども保険といえば「かんぽ」，といわ れるほどの加入者数を誇った ${ }^{13)}$ 。「学資保険」の普及により，我が国では， 未成年者を被保険者とする死亡保険に対する抵抗や批判というものはあまり 市民一般の議論とならず，広く受容される要因となったようである。その後， 民間保険会社によって，未成年者を被保険者とする死亡保険も発売されるよ

10）粟津清亮「簡易生命保険論」郵政省編『郵政百年史資料 第18巻 簡易保険論 纂 簡易保険官営論議』136頁（吉川弘文堂，1968年）参照。「今日卜雖卜モ幼 者ノ生命二就イテ多額ノ契約 7 許ストキハ或八此罪悪ノ発生ヨ誘導スルノ結果 アルベシ是レ小児/死亡保険力普通保険/範囲二入ラスシテ小額保険/領域二 属スル所以ニシテ而シテ簡便生命保険/実行八即チ此有益ナル小児保険 7 実行 セシムルノ利アルナリ」として民間生命保険会社に比して簡易保険の方が未成 年者の死亡保険につき道徳危険が低いと説いている。

11）田村・前掲注6) 84頁。徵兵保険とは 0 歳児から15歳までの男子を対象とし, 保険事故を「徵兵」とする生命保険であった。徵兵保険会社は小児保険と被保 険者の年齢がほぼ重複するため, 少なから影響を受けるとして強固に反対し た。

12）松本富雄「学資保険及び特別終身保険の誕生」時の法令 774 号10頁（1972）。

13）かんぽ生命の「学資保険」の新契約件数は2011年現在で約 22 万件。マーケッ トシェアは実績ベースで $33.5 \%$ と業界トップ。ただし，新契約件数は過去 10 年 の $1 / 3$ まで減少している。郵政民営化委員会第91回（平成24年11月22日）議 事録・同資料91-2-2参照。新規契約件数が減少した理由として，南方敏尚副社 長（かんぽ生命株式会社執行役）は, 学資保険の主たる加入目的は教育費の確 保であるにもかかわらず, かんぽ生命の学資保険は, 死亡保障が主な補償内容 であるため，顧客のニーズと乘離した，と説明している。 
未成年者を被保険者とする生命保険契約についての一考察

うになった。狭義の学資保険とは，子供の教育資金を目的とした保険契約を いうのであり，必ずしも未成年者を被保険者とする死亡保険契約を意味する ものではない。しかしながら，「学資保険」という商品名が，未成年者を被 保険者とする死亡保険契約であることを連想させないため，あるいは，死亡 保険契約として認識されなかったため, 結果として, 未成年者を被保険者と する死亡保険契約が広く普及する要因となったと思われる。

\section{（2）未成年者を被保険者とする死亡保険をめぐる学説}

我が国の未成年者を被保険者とする死亡保険契約は，以上のように，広く 一般に受容された。ただし，その実施についてはかねてより議論があった。 ひとつは被保険者の同意をめぐる法律論的な見地からの議論であり，もうひ とつは，未成年者保険その是非を含む政策論的な見地からの議論である。両 者は立法論・解釈論の交錯した領域の問題であるが，ここに主なものをまと め。

ア 法定代理人による同意についての問題

未成年者を被保険者とする死亡保険契約については，その同意のあり方を めぐって, かねてより議論があった ${ }^{14)}$ 。通説では, 他人の生命の保険契約に おける被保険者の同意は，当該保険契約の成立に向けた意思表示ではなく， 被保険者が自己の生命に関して保険契約が締結されることに同意する意思の 表明であり，準法律行為とされる。形式論としては，準法律行為には法律行 為に関する民法の一般原則が準用されるので，制限行為能力者である未成年 者の同意は，法定代理人による代理が可能であると解される ${ }^{15)}$ 。未成年者の

14）前掲注2)参照。例えば, 大森教授は, 被保険者が制限行為能力者である場合 は，民法の一般原則に従い，法定代理人による同意も可能と解するほかない， としながら，諸外国の例をあげ，立法論としては，法定代理人による同意を認 めることは問題であるとする。また, 山下教授は, 被保険者の意思能力がある 場合には，法定代理人が代理する方法によらず，被保険者本人の同意も要求す ることが望ましいとする。

15）大森・前掲注2)271頁，西嶋・前掲注1) 324頁。 
同意をめぐる主な学説をまとめると，以下の通りである。

(1)法定代理人が代理して同意することを認める ${ }^{16)}$

(2)意思能力のない未成年者については法定代理人が代理して同意し，意思 能力のある未成年者については本人が同意したうえ法定代理人が同意す ることを認める ${ }^{17)}$

(3)法定代理人による代理の同意を認めない ${ }^{18)}$

(4)意思能力のない未成年者については法定代理人による同意を認めず，意 思能力のある未成年者については本人が同意した上で, 法定代理人がこ れに同意する ${ }^{19}$

(1)の根拠としては，先に挙げたように同意は準法律行為であるから，民法 の一般原則を類推適用すべきこと，また，とくに意思能力のない未成年者の 被保険者の同意には，民法上の親権者の財産管理権・身上監護権が及ぶなど として ${ }^{20)}$ ，代理の同意を認めるとする。その他，法定代理人が被保険者同意 について代理権を有しないものとすれば，未成年者自身が被保険者同意をな す場合に法定代理人の同意は不要であることになり，未成年者が独断で被保 険者の同意をすることを認めることになるが，これは危険である，という説 もある ${ }^{21)}$ 。

16）大森・前掲注2) 271頁，西嶋・前掲注1)324頁等。ただし，ぞの論者も，法定 代理人による同意で問題がないとしているわけではない。

17）山下・前掲注2) 272頁，江頭憲治郎「他人の生命の保険契約」ジュリスト 764 号64頁 (1982) 参照。

18）田中誠二・保険法265頁（千倉書房，1987）参照。

19）福田弥夫「他人の生命の保険契約」日大法学紀要 27 卷 275 頁参照。意思能力 のない未成年者については，付保禁止または保険金額を制限すべきとする。

20）西村高等法務研究所「未成年者を被保険者とする生命保険契約に関する調查 研究」報告書（2007年 9 月 7 日） 9 頁，

http://www.jurists.co.jp/ja/nials/news_b/pdf/report_0709.pdf 参照。酒巻 宏明「未成年者を被保険者とする保険」金澤理監修=大塚英明＝児玉康夫編・ 新保険法と保険契約法理の新たな展開223頁（ぎょうせい，2009年）参照。

21）松本丞治「他人ノ生命ノ死亡保険二於ケル被保険者ノ同意二付テ」私法論文 集〈復刻版〉219頁（有斐閣，1989）参照。 
未成年者を被保険者とする生命保険契約についての一考察

(1)に対する批判としては，被保険者の意思能力の有無を問わず，法定代理 人が被保険者に代理して同意することについては実質同意の空洞化であって， 同意によって期待される道徳危険の防止の機能が果なせない点から，制限を 付けるべきであるとする説 ${ }^{22)}$ や，法定代理の同意は実質的に利益相反行為 (民826条) にあたるという説もある ${ }^{23)}$ 。(2)は，この点につき，意思能力のあ る未成年者については本人が同意をなした上で法定代理人が同意をなすべき であるというものである。実務上の処理もこの方法で行われている。具体的 には，15歳未満の場合には，法定代理人の同意を取得し，被保険者が15歳以 上の場合には，本人および法定代理人の同意を取得している。また，意思能 力のない未成年者を被保険者とする保険契約の場合は，道徳危険の防止の点 から，保険金額を制限するべきであるという説もある ${ }^{24)}$ 。

(3)の根拠としては，(1)の批判として上に挙げたものの他，同意は人格権の 行使として一身専属的性質を有するから法定代理に親しまないとするものな どがある ${ }^{25)}$ 。そもそも，未成年者といえども自己の生命への危険を伴う保険 契約につき被保険者となることの決定は被保険者自身に委ねられるべきであ り，意思能力のある未成年者の場合は，被保険者自身に判断させるべきであ ろう。ただし，法定代理人による代理同意を認めないと，未成年者を被保険 者とする保険契約の社会的有用性を損なうため, (4)では意思能力の有無で判 断するものである。実質的には意思能力のない未成年者を被保険者とする保 険契約は制限されることになる ${ }^{26)}$

イ未成年者を被保険者とする死亡保険契約の政策論的議論

未成年者を被保険者とする死亡保険契約については，政策論的になんらか

22）大森・前掲注2)271頁，西嶋 - 前掲注1) 324頁。

23）山下・前掲注2) 272頁。

24）江頭・前掲注17)64頁参照。

25）田中・前掲注18) 265頁参照。解釈論としても，同意は代理に親しまないもの と解すべきであるとする。

26）福田・前掲注19)275頁参照。なお，山下・前掲注2)272頁参照。そもそも, 未成年者，とりわけ幼児の保険を認めるべきかは，政策的問題があるとする。 
の制限措置が必要ではないのかという議論がある。

(1)未成年者の死亡保険契約を全て認めない

(2)未成年者の死亡保険契約について，保険金額の制限措置が必要

(3)未成年者の死亡保険契約について，被保険者の年齢制限措置が必要

(4)未成年者の死亡保険契約について制限すべきではない

(4)以外は，未成年者の死亡保険契約を無制限に認めるべきではないという 立場である。一律に禁止するというのは困難であるとしても，未成年者を被 保険者とする死亡保険契約につき道徳危険を回避する必要性から，(2)(3のよ うな制限措置が必要であるという主張は多くの論者が述べているところであ

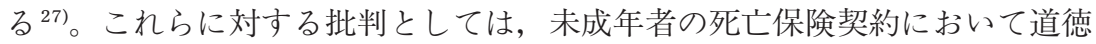
危険の弊害が顕著であるという証拠はないとするものや ${ }^{28)}$ ，未成年者の死亡 保険が一定のニーズがあるとする以上，保険金額を一律に制限すべきではな いとするもの ${ }^{29)}$ がある。また，道徳危険については法律上一律に禁止とし なくとも，保険会社各社において適切な募集体制や社内引受基準を構築し， 当該社内基準を厳正に遵守していくことで十分に担保できる30)というもの

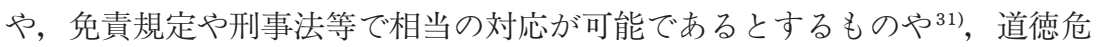
険に対しては保険者も被害を蒙るのであるから，実務上保険者は個々の事案 ごとに慎重な引受審査をしていること融などがあげられる。

27）西嶋・前掲注2) 325頁，山下 - 前掲注2) 272頁，江頭・前掲注17)64頁参照。 これらには，保険金額を葬祭費用程度に制限し，それを超過した場合は，立法 論としてこの種の保険契約を禁止すべきとするものや，意思能力のない未成年 者については禁止すべきとするもの等がある。

28）西村高等法務研究所報告・前掲注20） 9 頁。

29）西村高等法務研究所報告・前掲注20） 9 頁。

30）酒卷・前掲注20) 225 頁。

31） 西村高等法務研究所報告・前掲注20) 6-7頁。

32）田口城「保険法現代化が生保実務に与える影響一プロ・ラタ主義の導入，未 成年者の保険の議論を中心に一」保険学杂誌599号130頁（2007）参照。 
未成年者を被保険者とする生命保険契約についての一考察

\section{（3）実務・監督庁の対応}

保険法制定にあたり，法務省法制審議会保険部会でも，未成年者を被保険 者とする死亡保険契約について議論がなされたが，特段の規定は盛り込まれ なかった。しかしながら，金融庁の金融審議会第二部会・保険の基本問題に 関するワーキンググループにおいても未成年者の死亡保険契約についての意 見が出され ${ }^{33)}$ ，これを受けて，「未成年者に対する死亡保険のうち，モラル リスクの高いものについては，金融庁，業界，保険会社各社において効果的 なモラルリスク対策を実施すべきである」とされた ${ }^{34)}$ 。結果，保険者による 自主規制の策定 ${ }^{35)}$ ，および金融庁によるその遵守の監督という方法がとられ ている（保険業法施行規則第53条の 7 第 2 項，監督指針 II - 3-5-1-2 (15))。

\section{(4) 小 括}

未成年者を被保険者とする死亡保険については，我が国で一定のニーズが あるものの，道徳危険排除の点から，これを無制限に認めるべきではないと いう主張が多くなされてきた。しかし，契約法上は特段の規律は設けられず， 未成年者の死亡保険問題は，「未成年者の同意を法定代理人が代理すること」 の問題から離れ，「保険者がいかに適正な運用を行うか」の問題（保険金額 の相当性および適切な引受・支払基準の構築，その遵守）に収束された。

\section{3 . 諸外国立法状況の検討}

比較法的検討として，諸外国の立法例を概観する。

33）金融審議会金融分科会第二部会（第46回）および「保険の基本問題に関する ワーキンググループ」（第44回）合同会合議事録。

34）金融審議会金融分科会第二部会（第46回）および「保険の基本問題に関する ワーキンググループ」（第44回）合同会合資料 2 「未成年者等の死亡保険にか かる当庁の対応 (案)」。

35）前掲注3）・注4）参照。また，未成年者を被保険者とする死亡保険については， その保険金額の上限を 1000 万円程度にする。 


\section{（1）各国の立法例}

未成年者を被保険者とする死亡保険について，諸外国では成年者と比して 制限されている場合が多い。各国の立法例について，アメリカ，イギリス， フランス，ドイツ，中国について概観する ${ }^{36)}$

イギリスは，上記中で唯一，未成年者を被保険者とする死亡保険契約を締 結できない。生命保険契約に厳格な被保険利益を必要とするイギリスでは, 自己および配偶者の生命については被保険利益を有するとし，この場合には， 被保険利益の存在について立証する必要はない。その他の場合は，金銭的利 益による被保険利益の存在が必要である。利益は金銭的に評価され，法律上

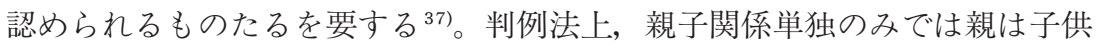
の生命に対して被保険利益を有しないとされ，生命保険契約を締結すること は不可能である ${ }^{38)}$ 。イギリス判例法によれば，法律上，親は子供を扶養する 義務がなく，子供も親を扶養する法的義務を負わないため，被保険利益を有 さないからだという39)。

アメリカもイギリスと同じく利益主義を採るが，親子間では緊密な家族関 係を基礎とした被保険利益が存在するとされ ${ }^{40)}$ ，未成年者を被保険者とする

36）これらの国々は世界の生命保険料収入べースでみた上位 6 か国である。出典 はスイス再保険が発表した World insurance in 2014,Sigma03/2014

(http://media.swissre.com/documents/sigma_3_2014_en.pdf) より。ちな みに 1 位はアメリカ， 2 位日本， 3 位イギリス，4 位フランス，5位中国，以 下イタリア，ドイツ，韓国と続く。

37）潘阿憲「生命保険契約における被保険利益の機能について」文研論集129号 130頁（1999年）参照。

38）潘・前掲注37)131頁参照。経済的利益があると認められた場合には被保険利 益があるとして，未成年者に対する死亡保険も認められる。

39）潘・前掲注37）140頁。親子間の扶養義務は，コモン・ロー上，道徳上の義務 だと考えられているという。

40）二ューヨーク州保険法第3205条 a 項 1 号「被保険利益という用語は, 次の 意味を有する。(A)血縁または法律上の近親者の場合においては，愛情および愛 着から生ずる実質的利害関係」。なお条文の翻訳については，今井薰＝梅津昭 彦監訳「ニューヨーク州保険法（2010年末版）」（生命保険協会，2012年）を参 
未成年者を被保険者とする生命保険契約についての一考察

死亡保険契約を締結することができる。ニューヨーク州保険法によると，14 歳 6 か月以上の未成年者については被保険者の書面による同意を必要とす る ${ }^{41)}$ 。すなわち，14歳 6 か月以上の未成年者は，保険契約について全ての権 利を行使する能力を有するものとみなされるからである。ただし, 当該未成 年者を被保険者とする死亡保険契約の保険金受取人は父母，配偶者，兄弟， 姉妹, 子もしくは祖父母に限られる ${ }^{42)}$ 。14歳 6 か月未満の未成年者について は書面による被保険者の同意を要求しないが，保険金額は制限される ${ }^{43)}$ 。

フランスにおいては，12歳未満の未成年者を被保険者とする死亡保険契約 は一律で制限し（フランス保険法 L. 132-3)，12歳以上の未成年者について は，親権者等の承諾に併せて，被保険者の書面による同意を必要とする（フ ランス保険法 L. 132-4)。フランスについては後に検討する。

ドイツ保険契約法は，2008年に新たに施行されたが，未成年者に関する規 定については従来とほぼ同じ条文である。他人の死亡保険契約で保険金額が 通常の葬祭費用の額を上回るときは，被保険者の書面による同意を必要とし， 被保険者が行為無能力者又は制限行為能力者である場合は，被保険者が同意 を与えた場合でも後見人は当該行為無能力者又は制限行為能力者を代理する ことはできないとする（ドイツ保険契約法150条 2 項）。また，父または母が， 未成年者の子を被保険者として保険契約を締結する場合に，被保険者が満 7 歳未満の死亡時に保険給付がなされるものであって，かつその給付額が通常 の葬祭費用の額 ${ }^{44)}$ を超えるときは，子の同意と特別代理人の選任を要求す

照した。

41）二ューヨーク州保険法3205条 c 項。14歳 6 か月以上の未成年者は，本条でい う契約締結能力のある被保険者であるので，被保険者本人の書面による同意を 必要とする。

42）二ューヨーク州保険法3207条 a 項参照。

43）二ューヨーク州保険法3207条 b 項参照。14歳 6 か月未満の未成年者について 被保険利益を有するものまたは扶養する者が, 5 万ドルまたは保険発効者の生 命に関する既契約生命保険金額の $50 \%$ 限度（4歳 6 か月未満の未成年者につい ては25\%限度）のいずれか大きい金額を超えない限度で締結可能とする。

44）大谷弘道「ドイツ人の片感覚」慶応義塾大学日吉紀要ドイツ語学・文学48 
る（ドイツ保険契約法 150 条 3 項）。

中国保険法 ${ }^{45)}$ は2009年に改正されたが，従来同様，人保険についても被 保険利益を必要とし, 被保険利益を有しない保険契約は無効である（中国保 険法31条)。その範囲は本人の他，配偶者，子，父母，保険契約者と扶養関 係を有するその他の家族，近親者，および保険契約者と勤労関係を有する者 である。中国では, 自然人の権利能力について，10歳未満を行為無能力者， 10歳以上18歳未満を制限行為能力者，18歳以上を完全な行為能力者とする (中国民法通則11条～13条)。行為無能力者を被保険者とする死亡保険は制限 されるが (中国保険法 33 条 1 項), 父母が10歳未満の未成年者の子のために 契約する生命保険は制限されない。ただし，その保険金額は保険監督管理機 関が定める額を超えてはならないとする (同条 2 項)。また, 被保険者の書 面による同意なき死亡保険契約は無効とするが (中国保険法34条 1 項), 父 母が10歳未満の未成年者の子を被保険者とする死亡保険契約を締結するとき は，同意は必要としない (同条 3 項)。ちなみに，他国の立法ではあまりみ られない中国保険法の立法として, 被保険者による保険金受取人の指定変更 権がある。被保険者は契約者の同意なしに保険金受取人の指定・変更をする ことが可能である (中国保険法39条・41条)。一方，契約者が保険金受取人を 指定・変更する場合は，被保険者の同意を得なければならない。実質的には 保険金受取人の指定・変更権は被保険者に帰属する ${ }^{46)}$ 。

卷26頁（2011）によると，きちんとした葬儀をするには，簡素な形であっても 平均 5,000 ユーロが必要であるという。葬祭費用は健康保険組合で賄われてき たが，2004年をもって「葬祭費」“Sterbegeld”制度は廃止され，個人で保険 に入って対応することが求められているという。

45）なお，条文の翻訳については，清河雅孝＝周テツ「2009年の中国改正保険 法」産大法学 43 巻 3 ・4 号（2010）を参照した。

46）李鳴「中国保険法の人保険契約における保険金受取人をめぐる諸問題」（保 険学雑誌615号，2011年）207頁参照。これについての中国の学説は, 以下の三 つの観点から一致して支持しているという。すなわち(1)被保険者は原始的な保 険金請求権者であり, 保険事故発生後は当該保険金請求権を行使することはで きないため, あらかじめ保険金受取人を指定し, 被保険者が享受する保険金請 
未成年者を被保険者とする生命保険契約についての一考察

\section{(2) フランスにおける状況}

フランス保険法は，L132-1条において，他人の生死を目的とした生命保 険契約を締結することを認めるが，L132-2条において，他人の生命の死亡 保険契約を締結する際には，被保険者による書面による同意がない場合はこ れを無効とする。これは，当該保険契約につき被保険者となることについて 承諾する，自己決定の意思表示であるとともに，保険金受取人に対する信頼 および危険の評価に対する許可の意思表示でもある ${ }^{47)}$ 。同時に，被保険者に よる同意は，道徳危険を回避するための措置でもある。すなわち，被保険者 の同意とは，他人の生命について適正な保険契約を締結するため，あらかじ め，契約申込者の votum mortis（近親者や契約相手方などについての死亡 願望）を排除するためのものであるという ${ }^{48)}$

未成年を被保険者とする保険契約については，L.132-3条および L. 132-4 条において，以下のように規定する。

L. 132-3条 12歳未満の未成年者, 成年被後見人，精神療養施設に収容さ れている者について死亡保険を締結することは，すべての者に対して禁止さ れる。

その禁止に違反して締結された保険はすべて無効である。（以下略）

L.132-4条 死亡保険契約は，12歳以上の未成年者について，親権を付与 された両親，後見人，財産管理人（curateur）の承諾なしに，他の者が締結 することはできない。

求権を実現させる。(2)被保険者は保険契約による保障を受ける真の主体であり, 被保険者は自己の生命により発生する経済的利益について当然に決定権を有す る。(3)契約者のみに保険金受取人の指定・変更権を付与するのでは道德危険を 排除できない。

47) BONNARD, J. (2007) Droit des assurances, 2e éd., Lexis Nexis Litec, p. 298.

48) MAYAUX, L. 《Les assurances de personnes》, Bigot, J. (2007) Traité de Droit des assurances, tome 4, L.G.D. J., p. 169. 
その承諾は，行為無能力者自身の同意を免除するものではない。（以下略）

L. 132-3条では12歳未満の未成年者についての死亡保険を一切制限する。 フランスでは未成年者の無能力は原則として一般的なものである。ドイツ法 や中国法等のように，年齢によって無能力者や制限行為能力者などの能力上 の区別をおこなわない。そのかわり，必要な場合には，行為能力について， それぞれの法律行為によって分けて考えている ${ }^{49)}$ 。生命保険について一定の 年齢制限を設定しようとした起源は，1904年当時の立法過程にみることがで きる。ただし，この時点では13歳から15歳の間で議論されていたが50)，1930 年 7 月 13 日付法 58 条で12歳未満とされた ${ }^{51)}$ 。このような契約は無効であるが, これは立法者が， votum mortis を排除しようとした規定であるという52)。 すなわち，このような保険を存在させることが，潜在的な道徳危険の誘因と なると考えられた。

L.132-4条では，12歳以上の未成年者を被保険者にする死亡保険につき， 本人の同意と共に親権者等の承諾を必要とする。親権者等の承諾をもっても， 被保険者本人の同意は免除されない。これは民法における遺言能力と同様の 規定である。16歳未満の者は遺言をなすについて絶対的無能力者である（フ ランス民法 903 条)。しかし，満16歳以上の未成年者は成年者が処分すること を許される財産の $1 / 2$ を限度として遺言で処分することができ，代理人はそ れを代理することはできない（フランス民法904条)。保険法でも同様に，無 能力者である未成年者に対してこのような権利を付与している。そしてこれ は, mutatis mutandis (不和により, 従来の関係を解消する効果を生む当 事者の意思）の場合を想定し，未成年者である被保険者をして当該保険契約

49）山口俊夫・概説フランス法(上)464頁（東京大学出版社，1978）参照。

50) GROUTEL, H. (2008) Traité du contrat d'assurance terrestre, Litec, p. 1400 .

51）フランス保険法の沿革については，青谷和夫「フランス保険契約法」比較法 制研究 4 号141頁 (1980), 笹本幸祐「フランス法の現状分析」保険学雑誌 615 号 (2011) 参照。

52) GROUTEL, op.cit., p. 1307. 
未成年者を被保険者とする生命保険契約についての一考察

の有効性につき自己決定できるようにしている。例外として，フランスには 親権開放という規定があり，この場合は未成年者であっても行為能力者とし てみなされる場合がある。未成年者が，満16歳に達した場合，父母又はその 一方の請求に基づき, 裁判官によって, 正当な事由があるときに, 親権解放 の宣言がされ得ることとされている（フランス民法477条）。なお，親権解放 の効果としては，未成年者にすべての民事行為につき行為能力を付与する ${ }^{53)}$

\section{(3) 小 括}

以上，諸外国の立法例を概観した。イギリスを除き，各国で未成年者を被 保険者とする死亡保険につき何等かの規定が存在するが，これら共通するの は，意思能力がある未成年者の被保険者については，法が本人の同意を必ず 要求とするということである。また，意思能力のない者，あるいは一定年齢 以下の未成年者を被保険者とする死亡保険契約の場合，これを完全に制限す るか (フランス)，被保険者の同意要件は緩和するものの保険金額を制限す るといった（アメリカ，ドイツ，中国)，何らかの規制が採られている。

己れら，未成年者を被保険者とする死亡保険に被保険者の同意を求める根 拠は，当該生命保険を承諾することの自己決定であり，また，同時に道徳危 険についての判断でもあるため，これを代理することはできないということ である。この点につき，形式的に代理で同意できるとする我が国とは状況が 異なっているといえよう。

\section{4.おわりに}

日本では，未成年者を被保険者とする死亡保険契約が広く受け入られてい るが，受容の契機となったのは，昭和初期に実施された簡保小児保険にあっ た。しかし，私見ではあるが，受容の背景となった学資保険については，そ

53）中国においても，同様な規定を置く。16歳以上18歳未満の者であって，主と して自己の収入で生計を立てている者であれば，完全な行為能力者とみなされ る (中国民法通則11条)。 
の名称から，死亡保険契約であることが十分に周知されているかどうかは疑 問である。その点を差し引いて，実際に未成年者の死亡保険契約について， 実務上どの程度のニーズがあるのだろうか ${ }^{54)}$

未成年者を被保険者とする死亡保険契約については，その是非をめぐって かねてより議論があったが，保険法制定にあたり，条文には特段の規定は盛 り込まれなかった。現行法上，被保険者同意については，法定代理人による 代理の同意があればよいと解釈されている一方，道徳危険については，保険 者の自主規制や金融庁の監督によって対応がなされている。結論的には，契 約法上の問題から離れ，保険金額の相当性および適切な引受・支払基準の構 築，その遵守など，運用上の問題に収束したといえる。ただし，保険法制定 での議論をみても明らかなように，立法上の課題がなくなったわけではない。 ひるがえって，フランス等諸外国に目を向けると，未成年者を被保険者と する死亡保険契約については，立法上の制限を設ける例が多数みられる。多 くの場合，意思能力の有無を判断材料とし，保険契約を禁止したり，保険金 額を制限したりしている。これは，被保険者の同意とは，当該保険について 了承する意思表示であるとともに，道徳危険を伴う保険についての自己決定 であるとして，未成年者といえども代理による同意を実質的に認めないので はないか。したがって，意思能力のない未成年者を被保険者とする場合には， これを禁止するか，保険金額を制限する立法が採られている。

日本では，過去の事例から，未成年者を被保険者とする生命保険契約にお ける道徳危険は多くないという指摘もあり，また，学資保険としての一定の ニーズが存在することから，法が一律に制限を加えることについての批判も 当然であると思われる。しかしながら，法定代理人が被保険者に代理して同

54）しかしながら，他国と比較してもかなり高い水準にあるといわれる我が国の 葬儀費用を鑑みると，未成年者を被保険者とする死亡保険契約にもある程度の ニーズがあることは否定できない。例えば，日本での葬儀費用の平均は $231 万$ 円であり，これはアメリカ44万円，イギリスの 12 万円などと比べるとかなり高 いという。島田裕巳・葬式は, 要らない（幻冬舎新書, 2010）参照。ただし, 筆者は今後の日本では葬儀費用が下落していくことを指摘する。 
未成年者を被保険者とする生命保険契約についての一考察

意してもよいということは，やはり実質上同意の空洞化であって，その点に 限れば，同意によって期待される道徳危険の防止の機能が果たせないのでは ないだろうか。成年者を被保険者とする場合には同意を必要としていながら， 未成年者の場合には代理同意を認めるということは，解釈上困難であるのは 間違いない。特に意思能力のない未成年者の死亡保険について，保険契約の 禁止あるいは保険金額の制限等の規制が必要であると思われる。立法上の規 制を置かないのであれば，例えば，我が国実務ではその保険金額を 1000 万円 までと制限する自主規制措置がとられているが，保険金額の相当性は，例え 私的自治の領域であったとしても，事実上の関係性に依拠すべきであり，検 討が必要である。その点について，例えば，被保険利益的な観念から，保険 金額の相当性を導き出し，あるいはこれを禁止するというような場合もあり うるのではないだろうか ${ }^{55)}$ 。ただし，我が国においては，生命保険に被保険 利益を必要としないため，具体的には，葬儀費用に限定するなどの保険金額 の上限を設けたり，あるいは親子関係についての一定の事実関係を必要とす るなど，解釈するほかない。

(筆者は高知短期大学講師)

55）利益主義と同意主義は対立する概念ではなく，併用できるとするものとして， 潘・前掲注37)の他, 今井薰「他人の生命の保険」倉澤康一郎編・生命保険の 法律問題金判986号72頁 (1996), 山野嘉朗・保険契約と消費者保護の法理40頁 （成文堂，2007）参照。 